УДК $78.01+78.05$

\title{
В. Іонов \\ ЦІННІСНО-СМИСЛОВИЙ ЗМІСТ СУЧАСНОЇ УКРАЇНСЬКОЇ МУЗИЧНОЇ ІСТОРІОГРАФІЇ: ДІАЛОГІЧНИЙ ПІДХІД
}

\begin{abstract}
У статті розкривається значення естетичного відношення в контексті сучасної музичної культури, визначається залежність між феноменом естетичного та ціннісно-смисловими інтенціями культури. Шляхом аналізу музикознавчих досліджень розкриваються особистіснотворчі чинники сучасної української музичної історіографії.
\end{abstract}

Ключові слова: естетичне відношення, поетика, ціннісно-смисловий тезаурус, діалог, особистісно-творча позиція.

Історіографічні тенденції музикознавства, відбиваючи своєрідність сучасної культурології, виражаються, окрім іншого, у становленні авторизованих галузей науки про музику, цікавих і важливих здатністю конкретного дослідника створювати оригінальну теорію і виражати в ній свій особистісний - не тільки професійний, але і життєвий - досвід. В останні десятиліття культурологія завойовує право розвиватися в контексті суб'єктивних поглядів, суджень, пристрастей, способів організації думки і мови. Можливо, тому найбільший резонанс як для культурології, так і для інших гуманітарних дисциплін (зокрема, мистецтвознавства, естетики) набувають ті роботи, які звернені до особистості як до «автора культури», узагалі до людського «авторства» у особистому та суспільному житті; частиною такого авторства стає художній задум.

Чи здатний гуманітарій до опанування ціннісно-смислового змісту культури та якою мірою музика причетна до його втілення? Яка залежність існує між ціннісно-смисловими інтенціями культури та феноменом естетичного? Чи можна вважати естетичне відношення універсальним проявом людяності, що так або інакше присутній у всіх формах людської життєдіяльності, але особливого значення набуває в процесі художньої творчості? Ці та деякі інші питання обумовлюють наступну низку роздумів як спробу визначити актуальні до сьогодні погляди на цілісно-смисловий зміст як на складову сучасної української музичної історіографії.

Почнемо з того, що завжди притаманне людині й завжди актуальне прагнення дійти до істини, тобто пізнати справжні причини, дієві

(C) Іонов В., 2014 
сили та мету людського існування, є чинником як мистецького, так і науково-теоретичного моделювання життєвих процесів. У цілому це моделювання утворює те, що прийнято називати гуманітарною культурою, гуманітарною формою знання, на відміну від так званих точних або природних наук. Загалом усе, що створене людиною, є гуманітарним витвором. Але зараз справа не в цьому, а в тому, що гуманітарій як творча особистість, чи є він митець-практик, чи є науковець-теоретик, працює саме 3 моделлю дійсності, а не з самою дійсністю, відтворює модель явища, а не саме явище, бо штучна модель дозволяє досить чітко визначати межу між відомим і ще не пізнаним. Водночас, чим глибше поринає гуманітарна думка, тим очевиднішим стає безпорадність - поки що та все ще - з'ясувати людську природу з усіма її складнощами, протиріччями тощо.

Впродовж останніх двох століть остаточно виявилось, що найбільш важкими питаннями для людини є питання про неї саму. А ці питання, як відомо, безпосередньо пов'язані з трагічним усвідомленням дійсності, насамперед, усвідомленням нездоланної антиномічності буття; власне ця антиномічність й породжує трагічне самовідчуття людини як світовідчуття: емоція, але емоція вищого рівня, сприймається, переживається як світогляд, стиснутий до точки, до спалаху чуттєвості. Звідси постійна таємниця естетичного переживання, яка стає необхідною ланкою такого переживання: позбавлене утаємниченості, переживання перестає бути глибинним естетичним... Саме тому естетичні емоції як «вищі», «складні», «трансцендентні» тощо $є$ важливим предметом художнього та наукового моделювання людської дійсності - бо, як людська, така дійсність сповнена чуттєвим досвідом, шо передує, за ствердженням багатьох психологів, усілякій розумовій діяльності, усілякому мисленню.

Таким чином, у центрі уваги митців й науковців, що прагнуть до осягнення ціннісно-смислового потенціалу культури, опиняється людина як суб'єкт діалогу з навколишнім, діалогу, активність якого примушує предметні реалії оточуючого світу займати позиції адресату чи адресанту - в залежності від обраного людиною типу діалогу. Мистецтву надається особливе право, але й особлива відповідальність, відтворення, скоріше навіть створення - виявлення у відчутній формі - такого діалогу. Тому й постає у якості провідної в мистецтвознавстві широкого профілю проблема поетики - художньо-естетичного моделювання дійсності з надією дійти до пізнання та розуміння. Тому будь-який естетичний феномен, взятий як худож- 
ній, може і повинен розглядатися як феномен поетики, тобто в широкому сенсі художньої дії, як результат прояву певного художнього методу зі всіма супроводжуючими його принципами. Саме це має на увазі М. Бахтін, коли пише: «Поняття естетичного не можна видобути з художнього твору інтуїтивним або емпіричним шляхом. Воно буде наївним, суб'єктивним та нестійким. Для впевненого і точного самовизначення йому необхідні взаємовизначення з іншими галузями у єдності людської культури» [2, с. 29].

Обговорюючи явище поетики, М. Бахтін пов'язує його саме 3 культурологічною галуззю, оскільки єдність мистецтва для нього, як і особистісна єдність, виражає цілісність людської культури. Отже, з одного боку, категорія поетики є своєрідним заступником феномену естетичного в області мистецтва, а з іншого боку, категорія поетики є цілковито культурологічною і змушує бачити в будь-якому художньому творі невід'ємну частину певної культури.

До поняття поетики своєрідно підходив і Л. Виготський (хоча прямо ним не користувався, замінюючи формулою «мистецтво як прийом»). I Бахтін, і Виготський говорять про художню форму як про своєрідне подолання матеріалу, звільнення від щоденних, ужиткових функцій мови і прояву того особливого смислу, що не може бути відокремленим від художньої форми. М. Бахтін з цього приводу пише: «Тільки в поезії мова розкриває всі свої можливості, але поезія настільки вимоглива до мови, що переборює ії як лінгвістичну визначеність. Художня творчість, що визначається по відношенню до матеріалу, і $є$ його переборювання» [1, с. 65]. Ця фраза дублює в багатьох відношеннях думку Виготського про те, що мистецтво відноситься до життя, як вино до винограду; в мистецтві художник створює машину, що «легше повітря», політ якої є великою таємницею, таємницею катарсису, насамперед [4, с. 309, 315-317]. Не користуючись даним терміном, Бахтін також приходить до визначення катартичних функцій художньої творчості; все, що він пише про взаємовідношення форми, матеріалу і змісту в художньому творі, прямо веде до того розуміння катарсису, яке виявляє праця Виготського. Подолання формою матеріалу, певний опір художньої форми життєвому матеріалу i, навпаки, - як пише Виготський, «...життєвий матеріал немовби всіма силами опирається тому, що хоче сказати митець» - ця взаємна боротьба призводить до деякої розрядки, образно-смислового замикання, особливого зіткнення афектів як до катарсису (за Виготським). 
Проблема поетики в музикознавстві невід'ємна від питань про значення і смисл в музичній мові, тобто питань про той план змісту, який звичайно називається в мовознавстві семантикою й оснований на єдності та протистоянні знакових та значеннєвих одиниць. В музиці будь-яке «висловлювання» (скористуємось терміном Бахтіна), будь-яке композиційне рішення є певний смисл або група смислів, протиставлення форми та змісту у звичному тлумаченні цих складових поетики фактично неможливо. Саме тому аналіз музичної семантики або, як пише Бахтін, естетичний аналіз - як смисловий, отже, i як ціннісний, в музиці є особливо складним.

Під ціннісно-смисловим тезаурусом культури, що виражається засобами музичної творчості і піддається історіологічному відтворенню та систематичному вивченню, можна розуміти:

- образно-смисловий зміст конкретного музичного твору;

- певну естетичну ідею, як вираження, передусім, естетичної позиції автора, його особистих настанов;

- поєднання, розташування образів-смислів, яке відповідає послідовності задуму автора і дозволяє говорити про музичну драматургію, незалежно від того, наскільки музичний зміст звертається до якогось предметно-дієвого ряду або уникає схожості з ним;

- усі процеси смислоутворення, тобто смислоутворюючі аспекти поетики як методу творчості, всі механізми створення музичного звучання, в тому числі ті, що презентують мовно-мовленнєві функції музики.

Втілюючи естетичне, художня форма створює умови для його впорядкування, відокремлення і розвитку, для його усвідомлення як певного досвіду спілкування людини зі світом (також самопізнання). Передумовою семантики (при іiї аналізі) можна вважати означення значень - способи знакової фіксації, тим самим розширюючи семантичний підхід до меж музичної поетики, охоплюючи останню. Безпосередньо семантика виявляється як пояснення вищеназваних відносин у музиці шляхом: а) звучання (безпосередньої реалізації в звучанні), що несе автономний досвід музики; б) найменування співвіднесеності звучання з вербальними визначеннями, своєрідними поняттями - віддзеркаленнями образних структур.

Проблема особисто-творчої спрямованості музичної історіографії розкривається як проблема вивчення людської індивідуальності, в тому числі мистецької індивідуальності, набуває у такій якості естетичного та психологічного резонансу. Але тому вона завжди несе пев- 
ну небезпеку розчинення у широкій галузі гуманітарного знання як сукупності підходів, питань та суперечностей. Тому дуже важливим здається те, що І. Драч задає названій проблемі свої питання, знаходить свої власні, обгрунтовані музикознавчим досвідом, підходи, викриває ті протиріччя, що можуть стати перешкодою до оригінальної концептуалізації (скористуємось авторським терміном) композиторської індивідуальності В. С. Губаренка [5]. Спеціально зупинимось на понятті концептуалізації. Його ми сприймаємо як знак переваги концепційного підходу, шо сьогодні стає все більш помітним у мистецтвознавчих та культурологічних працях, відповідаючи зростанню їх розуміючих тенденцій.

Надзвичайно важливим нам здається те, що у межах концепційного підходу I. Драч пропонує не тільки множинність аспектів актуалізації композиторської індивідуальності, а й виявляє складний зміст, смислову багаторівневість кожного з таких аспектів, що провокує до художньо-образного музичного відбиття, упорядкування таким, показовим для мистецького ставлення до життя, чином. У цьому сенсі особливо виокремлюються ті підрозділи дослідження, котрі дозволяють засвідчувати глибинні процеси формування музично-творчого задуму та його виходу на композиційно-драматургічну поверхню твору. По-перше, дослідниця виступає не лише об'єктивним дослідником, що володіє широкою, майже вичерпною, інформацією щодо причин виникнення даного музичного твору - до того ж взятих у контекстуальному вимірі, з ураховуванням природи усіх позамузичних компонентів, якщо йдеться про твір у синтетичному жанрі, про хід виконавського здійснення, про зовнішні та внутрішні фактори композиторської рефлексії. Вона намагається передати певним чином свою причетність до творчості Губаренка як тонкий слухач, співчуваюча людина, знаходячи власну семантику музикознавчого тексту, що досить виразно передає індивідуальне особистісне дослідницьке сприйняття творчості Губаренка в світлі проблеми композиторської індивідуальності. Здається, що така суб'єктивна зацікавленість, небайдужість до предмету вивчення є необхідною рисою гуманітарного дослідження; це його методична властивість як розуміючого, тобто це те, що сприяє успішній концептуалізації композиторської творчості як сучасного нам, близького до нас феномена.

По-друге, дослідження І. Драч дозволяє зрозуміти, чому проблема індивідуальності стає однією з провідних, навіть претендує на значення фундаментальної методологічної в системі сучасного знання: 
впродовж минулого століття невпинно зростає складність індивідуальної свідомості людини відповідно до стрімкого розширення інформаційного поля культури та до принципових змін в характері інформації (iї інтегрованості, з одного боку, стратифікації, з іншого, певного «омасовлення» - водночас герметичності, що потребує володіння особливими кодами тощо). 3 позиції змін у «смисловій побудові» (термін Л. Виготського) людської свідомості не лише відкриваються шляхи композиторського мислення, напрями творчої актуалізації композитора, а й пояснюються ті суто музичні ідеї та форми їх втілення в художній формі музики, що є справжнім змістом «модусів композиторської індивідуальності». Таким чином, музичний твір, що в своїй архітектоніці та семантичному наповненні наслідує індивідуальний духовний світ свого творця, стає тим матеріалом, на основі якого можна з достатньою впевненістю судити не лише про аспекти композиторської індивідуальності, а й про смислові домінанти культурного середовища, про близькі і далекі кола спілкування митця - як про такі, що зумовлюють «...все предметне буття художньої індивідуальності» і пояснюють, яким чином вона стає «джерелом творчої активності і причиною самої себе». Таке методичне прямування дисертаційної роботи підкріплюється розгорнутими аналітичними характеристиками значної кількості творів В. С. Губаренка; водночас, таким шляхом роз'яснюється, що «категоричний імператив» композиторської творчості є невід'ємним від живої тканини музичного твору, що в свою чергу «вплітається» в структуру музичного тексту на жанрово-стильовому рівні, тобто стає елементом в загальній системі музичного мовлення, додаючи до неї індивідуалізовані складові. Таким чином, як нам думається, індивідуальні «компоненти стилю» композитора не залишаються лише приналежністю його особистісної свідомості. Вони сприяють тому процесу авторизації музичного стилю, що активно відбувається в композиторській творчості XX століття; твори В. С. Губаренка складаються в таку авторизовану стильову парадигму для української музики останньої треті минулого століття, і концепція І. Драч дозволяє зрозуміти, завдяки чому і яким чином це відбувається.

Теоретична модель дослідження, що презентує модель авторської концептуалізації, стосується не лише проблеми композиторської індивідуальності, а й тенденцій трактування людської індивідуальності у цілому. Виникає досить широке охоплення феномену індивідуальності, навіть можна казати про дослідницькі пропозиції щодо син- 
тезу методів при вивченні креативних сторін людської особистості/ індивідуальності. Зокрема, звернемо увагу на синонімізацію понять «цілісність художнього світу митця» та «індивідуальність», бо вона нагадує про думку М. Бахтіна: «Три галузі людської культури - наука, мистецтво та життя - знаходять свою єдність тільки в особистості, яка залучає їх до своєї єдності... Мистецтво й життя не одне, але повинно стати в мені єдиним, в єдності моєї відповідальності». Це висловлення М. Бахтіна (в статті «Мистецтво та відповідальність» $[3$, c. 8]) можна прийняти як певний методичний заклик до вивчення людської особистості з її неповторними, водночас типовими психологічними рисами. І цілком зрозуміло, що саме особистість композитора як «героя культури» - але героя в тому розумінні, що пропонує саме психологічна думка другої половини XX століття, - як того, хто здатний відмовитись від особистого добробуту задля вищої духовної мети, тобто «героя-жертви», стає особливим внутрішнім предметом музикознавчих та культурологічних дисертаційних робіт та статей.

Так, поєднуючи історико-культурознавчу широту підходу до вивчення творчих засад митця з увагою до індивідуально-біографічних подробиць становлення його особистості, Т. Дубровний надає нових критеріїв вивчення фортепіанної спадщини А. Кос-Анатольського, визначення ключових моментів стильового мислення та стилістичного вибору композитора, взагалі веде до суттєво оновленого висвітлення постаті українського композитора. Більш того, розроблений в дисертації підхід до творчості Кос-Анатольського утворює таку теоретичну констеляцію, до якої можна с достатньою впевненістю залучити вивчення стильового прямування української композиторської школи як цілісного творчого феномену, починаючи з другої половини XX століття і дотепер [6].

Таким чином, в дослідженні на матеріалі творчості А. Кос-Анатольського на високому щаблі переконливості розробляється теоретична модель стилетворчого процесу в українській композиторській творчості, що здатна набувати значення самостійної наукової музикознавчої парадигми.

3 іншого боку, звернення до музики Кос-Анатольського (взагалі до феномену музичного мислення та стилеутворення) має результатом не лише доведення синтагматичного плюралізму естетики постмодернізму, а й справді революційне відкриття тісного зв'язку «мовно-стильових канонів національного постмодернізму» 3 феноменом соцреалізму, що дозволяє вбачати в соцреалізмі період раннього 
постмодернізму i, таким чином, суттєво змінювати його музикознавчі оцінки, розробляти принципово інші методи його вивчення, реабілітувати його значення як певного історичного етапу становлення національної художньо-естетичної свідомості.

Але й на цьому не зупиняється організована дослідженням Т. Дубровного реконструкція музикознавчої теорії стиля. Проміж явищами та поняттями соцреалізму - раннього постмодернізму встає музичний академізм, поняття про який виявляється рівною мірою тотожнім двом попереднім. Відразу скажемо, що цей «революційний» порив здається нам дещо зайвим, оскільки, по-перше, поняття музичного академізму не допомагає авторові вдосконалювати теоретичну конструкцію, навпаки, ії обтяжує, що, очевидно, відчуває й сам автор; по-друге, виникає нова несподіванка: прирівнювання явищ продовжується, і тепер вже знак тотожності єднає академізм і неоромантизм, що, за нашою думкою, вже остаточно позбавляє включення поняття академізму до основної теоретичної конструкції роботи методичної коректності, звідси - доцільності; по-третє, і це, можливо, $є$ головною причиною попередніх непорозумінь, поняття академізму належить до іншого рівня, класу явищ, аніж соцреалізм, тим більше постмодернізм. Вже зв'язок між двома останніми поняттями викликає певну дискурсивну напругу, але ця напруга має плідне теоретичне розв'язання, бо загальний хід дослідження дійсно дозволяє доводити приналежність постмодернізму і соцреалізму до одного плану культурної свідомості. Хоча, задля справедливості, відзначимо, що автор прямо цього не формулює, так само, як не дає достатньо прямої відповіді на питання - що ж таке постмодернізм? Водночас звернення до явища романтизму (пізнього романтизму, неоромантизму), про значення котрого дуже красномовно говориться, виявляється вдалим доповненням діалогічної пари постмодернізм - соцреалізм, до того ж з обох боків, і саме тому, що романтизм в українській музиці приймає понадстильову (зверхстильову) форму, сягаючи рівня метода i типа культурного мислення, організації культурної свідомості.

Саме тут і зустрічається так витлумачений романтизм з постмодернізмом та соцреалізмом - в тому вимірі культури, що, нагадаємо, відповідає за міру людського в людині, тобто в вимірі культурної автокомунікації - рефлексії - самоусвідомлення. Отже, постмодернізм може визначатись як тип організації культурної свідомості, вищий навіть за «стиль культури», бо він $є$ тим, що цей стиль визначає, - цілісною установкою культури, що може прийматись як методична, оскіль- 
ки дозволяє культурі встановлювати свої власні універсалії, канони мислення та мовлення. 3 усіх положень роботи Дубровного, дотичних до визначення постмодернізму, найбільш адекватними здаються положення про систему естетичних координат як «своє інше», що допомагає глибинно переосмислити творчість Кос-Анатольського, і апеляція до поняття «постмодерністичної поетики».

Таким чином, можна дійти висновку, що актуальність, водночас проблемно-тематична узагальненість праць ряду українських дослідників зумовлюються тим, шо феномен музичної культури стає спеціальним предметом наукової музикознавчої уваги як стильова художньо-естетична єдність типових жанрових структур та оригінальних композиторських задумів. Водночас автори створюють певну антологію персоналій, причетних до становлення музичного мистецтва та музичної освіти в Україні, справедливо виводячи на перше місце за художньою значущістю дійсно непересічну творчу особистість. Таким чином, діяльність останньої у сукупності їі зовнішніх структурно-функціональних та внутрішніх особистісно-психологічних ознак отримує такий широкий дослідний контекст, яким є історія та теорія музики - і цей контекст висвітлений у більшості робіт настійливо і з достатньою повнотою. Цьому значною мірою сприяє аналіз музикознавчих досліджень, дотичних до явища музичної історії та історії культури, тобто сфери, що стає свого роду теоретичним трампліном для історіографічної концепції.

\section{СПИСОК ЛІТЕРАТУРИ}

1. Бахтин М. Вопросы литературы и эстетики. Исследования разных лет / М. Бахтин. - М. : Худ. лит., 1975. - 502 с.

2. Бахтин М. Автор и герой в эстетической деятельности // Эстетика словесного творчества / [сост. С. Бочаров, прим. С. Бочарова, С. Аверинцева]. [2-е изд.]. - М. : Искусство, 1986. - С. 9-191.

3. Бахтин М. Искусство и ответственность // Эстетика словесного творчества / М. Бахтин. - М., 1986. - С. 7-8.

4. Выготский Л. Психология искусства / Л. Выготский. - М. : Искусство, 1968. $-576 \mathrm{c}$.

5. Драч I. Композитор Віталій Губаренко : формула індивідуальності : монографія / І. Драч. - Суми : СДПУ ім. А. С. Макаренка, 2002. - 228 с.

6. Дубровний Т. Фортепіанна творчість Анатолія Кос-Анатольського у стилетворчих процесах другої половини XX століття : автореф. дис. ... канд. мистецтв. : спец. 17.00.03 «Музичне мистецтво» / Т. М. Дубровний. - Львів, 2006. $-19 \mathrm{c}$. 
Ионов В. Ценностно-смысловое содержание современной украинской музыкальной историографии: диалогический подход. В статье раскрывается значение эстетического отношения в контексте современной музыкальной культуры, определяется зависимость между феноменом эстетического и ценностносмысловыми интенциями культуры. Путем анализа музыковедческих исследований раскрываются личностно-творческие факторы современной украинской музыкальной историографии.

Ключевые слова: эстетическое отношение, поэтика, ценностносмысловой тезаурус, диалог, личностно-творческая позиция.

Ionov V. Valued-semantic contents of modern Ukrainian musical historiography: dialogic approach. Article is devoted to the value of aesthetic attitude in the context of modern musical culture, dependence is determined between the phenomenon aesthetic and valued-personal-creative factors of the modern Ukrainian musical semantic intensions culture. Historiographies open up by the analysis of musicology researches.

Key words: aesthetic attitude, poetics, valued-semantic thesaurus, dialogue, personal-creative.

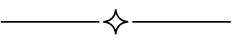

УДК 78.03+78.071.1

\author{
С. Поляковская
}

\title{
ОТ ЗАМЫСЛА К ВОПЛОЩЕНИЮ: КОММЕНТАРИЙ КОМПОЗИТОРА (ПО МАТЕРИАЛАМ ИНТЕРВЬЮ С АЛЕКСАНДРОМ КРАСОТОВЫМ)
}

Содержание статьи находится в кругу проблематики развития современного оперного искусства в Украине. В основу положен материал интервью с одесским композитором А. Красотовым, в котором обсуждаются вопросы стабильности жанрових черт оперы, актуальности традиционных оперных форм, стилистики современного музыкального язы$\kappa a$, специфики оперной драматурги, исполнительской интерпретации и роли музыкальной критики в освещении фактов оперных премьер.

Ключевые слова: опера, оперное творчество А. Красотова, жсанровые черты, стилистика современного музыкального языка.

Пути развития оперного жанра, его жизнеспособность на современном этапе, проблемы и перспективы функционирования оперного театра широко обсуждаются на страницах публикаций музыковедов, культурологов и социологов. От момента зарождения на рубеже

(C) Поляковская С., 2014 